\title{
NANOTUBS INCREASE TETRACHLOROMETHANE INDUCED OXIDATIVE STRESS
}

\author{
N. Ya. Letniak, I. P. Kuzmak, M. M. Korda \\ I. HORBACHEVSKY TERNOPIL STATE MEDICAL UNIVERSITY
}

\begin{abstract}
Background. The unique physical and chemical properties of carbon nanotubes determine wide-ranging prospects for their use in biology and medicine. The capability of nanotubes to transport medicines and chemicals inside a cell makes the possibility of classical toxicants toxicity increase in case of their intake to the body with nanotubes, an urgent issue.

Objective. The aim of the research was to study the effect of carbon nanotubes on the capability of the chemical toxicant tetrachloromethane (TCM) to induce oxidative stress in serum and liver of rats.

Methods. The experiments were performed on outbred male rats, which were administered intraperitoneally with $0.5 \mathrm{ml}$ of suspension of single-walled, multi-walled or multi-walled functionalized COOH nanotubes (60 mg/ $\mathrm{kg}$ ) only or together with TCM (2 ml/ $\mathrm{kg})$. The animals were taken out of the experiment in 3, 6 and 48 hours after the administration of the nanotubes and TCM. The activity of catalase, superoxide dismutase, the content of thiobarbituric acid reactive substances (TARS), reduced glutathione, ceruloplasmin and total antioxidant activity of serum were determined in serum and liver.

Results. It was established that under the influence of multi-walled carbon nanotubes the studied parameters changed significantly. The administration of tetrachloromethane to rats caused significant changes in all indicators. Maximal changes in the rates were recorded in the group of animals that were administered with carbon nanotubes and tetrachloromethane togeather. In this case, a number of the studied parameters of blood and liver significantly changed compare to the similar indicators of the group of animals, which were administered with the chemical toxicant only.
\end{abstract}

Conclusions. Carbon nanotubes increase the capability of the chemical toxicant tetrachloride to cause oxidative stress in liver and serum.

KEY WORDS: carbon nanotubes; tetrachloromethane; oxidative stress; rats.

\section{Introduction}

Nanotechnology today is the most promising direction in the development of world science. Nanomaterials have caused a step forward in many industries and are used in our overall life. Carbon nanotubes (CNT) are one of the priority types of nanomaterials. They are multifunctional materials that are actively studied due to their unique physical and chemical properties $[2,6]$. They exist in various forms and can be chemically modified by functional groups of biomolecules. CNT have unique mechanical, electrical and thermal properties and are widely used in various industries. Nanotubes are a promising nanomaterial for medical use due to their really high biocompatibility with blood, bones, cartilages and soft tissues

Corresponding author: Nataliia Letniak, Department of Biochemistry, I. Horbachevsky Ternopil State Medical University, 1 Maidan Voli, Ternopil, Ukraine, 46001

Phone number: +380352254784

E-mail: letnyak@tdmu.edu.ua
$[7,9]$. They can be used to create artificial heart valves, for the diagnosis and treatment of cancer, as well as for the transport of proteins, antigens, genes, vaccines and medicinal substances into a cell.

Due to everyday increase of nanomaterial use, less attention is paid to the possible negative effects of nanoparticles on environment and on people's health as a whole [14]. Small size, specific structure, large surface area, and chemical composition alert of possible toxic effects on the human body. Apart from the direct influence of carbon nanotubes on cells, they may interact with classical toxicants, e.g. tetrachloromethane (TCM). Currently, the issue of biological effects of nanoparticles in case of their intake to the body together with traditional toxicants is urgent. Thus it is necessary to study the toxicological properties of carbon nanotubes alone as well as in case of their intake to the body together with a toxicant. 
The aim of the research was to study the effect of carbon nanotubes on the capability of the chemical toxicant tetrachloromethane (TCM) to induce oxidative stress in serum and liver of experimental rats.

\section{Methods}

The experiments were performed on outbred male rats, $160 \mathrm{~g}$ in weight, which were kept on a standard vivarium diet. Single-walled (SWNT), multi-waledl (MWNT) and multi-walled functionalized (MWNT-COOH) nanotubes were administered to the animals in suspension $(0.5 \mathrm{ml})$ intraperitoneally at a dose of $60 \mathrm{mg} / \mathrm{kg}$. TCM was administered intraperitoneally in 50\% oily solution at a dose of $2 \mathrm{ml} / \mathrm{kg}$ just the once. Dispersion of nanoparticles in distilled water or TCM solution was carried out by means of the ultrasonic disperser UZDN-M750T $(20-25 \mathrm{kHz}$, $750 \mathrm{~W}$ ) for 5 minutes. The experimental animals were divided into 8 groups: the $1^{\text {st }}$ - the control (intact rats), administered with physical solution $(0.5 \mathrm{ml} / \mathrm{kg})$; the $2^{\text {nd }}$ - the rats administered with SWNT, the $3^{\text {rd }}$ - the animals administered with MWNT, the $4^{\text {th }}$ - the rats administered with MWNT- $\mathrm{COOH}$, the $5^{\text {th }}$ - the animals administered with TCM, the $6^{\text {th }}$ - the rats administered with SWNT suspension together with TCM, the $7^{\text {th }}-$ the rats administered with thesuspension of MWNT+TCM, the $8^{\text {th }}$ - the animals administered with the suspension of MWNT-COOH+TCM. The animals were taken out of the experiment under thiopental anesthesia in 3,6 and 48 hours after the injection. Liver homogenate and blood serum were the objects of the study.

The animals were kept and the experiments were conducted in accordance with the guidelines of European Convention for the Protection of Vertebrate Animals used for Experimental and Other Scientific Purposes.

The state of antioxidant system was evaluated by the activity of enzymes of superoxide dismutase (SOD) [8], catalase (CT) [4], the content of ceruloplasmin (CP) [10] and reduced glutathione (GSH) [3]. The development of oxidative processes in the body was evidenced by the content of products that react with thiobarbituric acid (TBARs) [1]. The total antioxidant activity (TAA) of plasma was also determined [13].

The nanopowder of single-walled carbon nanotubes (SWCN, 90\%, 1-2 nm), multi-walled nanotubes (MWCN, 99\%, 13-18 nm) and carboxyfunctionalized nanotubes (MWCN-COOH, 95\%, 30-50 nm)) produced by USResearch Nanomaterials, Inc. (USA) were used in the experiment. Tetrachloromethane produced by
Makrokhim (Ukraine) was used as a model toxicant.

Statistical processing of the results was performed at the Department of System Statistical Study of I. Horbachevsky Ternopil State Medical University using the software package Statsoft STATISTICA. The obtained indexes were compared using the MannWhitney non-parametric test. The changes were statistically significant at $p<0.05$.

\section{Results}

In 3 and 6 hours after the administration of MWNT, the activity of SOD significantly decreased in serum and liver compared to the control. After the administration of MWNT$\mathrm{COOH}$, the changes in the SOD content in both tissues were significant only by the $6^{\text {th }}$ hour of the experiment. At the same time, SWNT did not caused significant changes of this parameter. Another antioxidant defense enzyme that functions in blood and intercepts reactive oxygen intermediates is the CP. The content of $\mathrm{CP}$ in the blood of the animals administered with MWNT significantly exceeded the control indices in 1.3 times by the $6^{\text {th }}$ hour of the experiment. After administration of nanotubes to the experimental animals, the processes of lipoperoxidation increased that was evidenced by the increase in the content of TBARs in serum and liver. Thus, in cases of MWNT administration, the TBARs content in serum was significantly higher in 1.3 and 1.4 times compare to the control group of animals, respectively by the $3^{\text {rd }}$ and $6^{\text {th }}$ hours of the experiment. In cases of SWNT and MWNT-COOH administration, the significant increase of this indicator was evidenced only by the $6^{\text {th }}$ hour after injection.

A significant increase in CT activity was observed in cases of the administration of SWNT and MWNT-COOH by the $6^{\text {th }}$ hour of the experiment (in 1.2 and 1.4 times respectively), as well as in 1.3 and 1.5 times by the $3^{\text {rd }}$ and $6^{\text {th }}$ hours after the administration of MWNT.

The reduced glutathione is one of the main antioxidants of non-enzymatic nature, its deficiency in tissues or blood causes significant oxidative stress [12]. As presented in Table 1, the administration of MWNT to animals caused a significant decrease in the content of reduced glutathione in 3 and 6 hours after injection, respectively in 1.3 and 1.5 times compared to the control, as well as in 1.4 times in 6 hours after the MWNT-COOH administration. The plasma TAA varied equally to the GSH. It should be noted that all the indices changed wavelike, 
Table 1. The influence of carbon nanotubes on the indices of oxidative stress intensity in blood serum and liver of rats $(M \pm m, n=8)$

\begin{tabular}{|c|c|c|c|c|c|c|c|c|c|c|}
\hline \multirow{4}{*}{ Index } & \multicolumn{10}{|c|}{ Groups of animals } \\
\hline & \multirow{3}{*}{ Intact } & \multicolumn{3}{|c|}{ SWNT } & \multicolumn{3}{|c|}{ MWNT } & \multicolumn{3}{|c|}{ MWNT-COOH } \\
\hline & & \multicolumn{9}{|c|}{ Time after the administration (hours) } \\
\hline & & 3 & 6 & 48 & 3 & 6 & 48 & 3 & 6 & 48 \\
\hline & \multicolumn{10}{|c|}{ Blood plasma } \\
\hline $\begin{array}{l}\text { TBARs, } \\
\mu \mathrm{mol} / \mathrm{l}\end{array}$ & $\begin{array}{c}7.81 \\
\pm 0.43\end{array}$ & $\begin{array}{c}8.05 \\
\pm 0.51\end{array}$ & $\begin{array}{l}9.37 * \\
\pm 0.49\end{array}$ & $\begin{array}{c}7.35 \\
\pm 0.38\end{array}$ & $\begin{array}{l}10.05^{\star} \\
\pm 0.56\end{array}$ & $\begin{array}{l}11.09 * \\
\pm 0.61\end{array}$ & $\begin{array}{c}8.18 \\
\pm 0.39\end{array}$ & $\begin{array}{c}8.95 \\
\pm 0.41\end{array}$ & $\begin{array}{l}10.11^{*} \\
\pm 0.43\end{array}$ & $\begin{array}{c}7.95 \\
\pm 0.41\end{array}$ \\
\hline $\begin{array}{c}\mathrm{GSH}, \\
\mathrm{mmol} / \mathrm{l}\end{array}$ & $\begin{array}{c}2.73 \\
\pm 0.19\end{array}$ & $\begin{array}{c}2.55 \\
\pm 0.16\end{array}$ & $\begin{array}{c}2.17 \\
\pm 0.13\end{array}$ & $\begin{array}{c}2.61 \\
\pm 0.14\end{array}$ & $\begin{array}{l}2.14^{*} \\
\pm 0.15\end{array}$ & $\begin{array}{l}1.72^{*} \\
\pm 0.14\end{array}$ & $\begin{array}{c}2.65 \\
\pm 0.16\end{array}$ & $\begin{array}{c}2.41 \\
\pm 0.15\end{array}$ & $\begin{array}{l}1.98 * \\
\pm 0.14\end{array}$ & $\begin{array}{c}2.52 \\
\pm 0.18\end{array}$ \\
\hline $\begin{array}{c}\mathrm{CT} \\
\mathrm{MAb} / \mathrm{I}\end{array}$ & $\begin{array}{c}0.67 \\
\pm 0.04\end{array}$ & $\begin{array}{c}0.79 \\
\pm 0.05\end{array}$ & $\begin{array}{l}0.81 \text { * } \\
\pm 0.04\end{array}$ & $\begin{array}{c}0.63 \\
\pm 0.06\end{array}$ & $\begin{array}{l}0.89 * \\
\pm 0.03\end{array}$ & $\begin{array}{l}1.00 * \\
\pm 0.07\end{array}$ & $\begin{array}{c}0.78 \\
\pm 0.03\end{array}$ & $\begin{array}{c}0.82 \\
\pm 0.04\end{array}$ & $\begin{array}{l}0.93 * \\
\pm 0.06\end{array}$ & $\begin{array}{c}0.60 \\
\pm 0.04\end{array}$ \\
\hline $\mathrm{CP}, \mathrm{mg} / \mathrm{l}$ & $\begin{array}{l}238.4 \\
\pm 9.20\end{array}$ & $\begin{array}{l}247.9 \\
\pm 9.85\end{array}$ & $\begin{array}{l}257.3 \\
\pm 8.01\end{array}$ & $\begin{array}{r}245.7 \\
\pm 10.04\end{array}$ & $\begin{array}{c}261.7 \\
\pm 10.65\end{array}$ & $\begin{array}{l}285.5^{*} \\
\pm 11.45\end{array}$ & $\begin{array}{l}251.3 \\
\pm 8.95\end{array}$ & $\begin{array}{l}258.1 \\
\pm 8.40\end{array}$ & $\begin{array}{l}269.6^{*} \\
\pm 10.25\end{array}$ & $\begin{array}{l}255.4 \\
\pm 8.83\end{array}$ \\
\hline TAA, \% & $\begin{array}{l}61.49 \\
\pm 4.10\end{array}$ & $\begin{array}{l}60.72 \\
\pm 3.52\end{array}$ & $\begin{array}{l}58.05 \\
\pm 2.70\end{array}$ & $\begin{array}{c}61.1 \\
\pm 4.26\end{array}$ & $\begin{array}{l}53.31 \\
\pm 3.02 \\
\end{array}$ & $\begin{array}{l}45.57^{\star} \\
\pm 2.98\end{array}$ & $\begin{array}{l}55.13 \\
\pm 4.05\end{array}$ & $\begin{array}{l}57.45 \\
\pm 3.80\end{array}$ & $\begin{array}{c}50.23^{*} \\
\pm 2.75\end{array}$ & $\begin{array}{l}59.01 \\
\pm 5.12\end{array}$ \\
\hline $\begin{array}{c}\text { SOD, units/ } \\
\text { ml }\end{array}$ & $\begin{array}{c}8.33 \\
\pm 0.54\end{array}$ & $\begin{array}{c}7.62 \\
\pm 0.60\end{array}$ & $\begin{array}{c}7.02 \\
\pm 0.48\end{array}$ & $\begin{array}{c}8.16 \\
\pm 0.53\end{array}$ & $\begin{array}{l}6.65 * \\
\pm 0.51\end{array}$ & $\begin{array}{l}6.30 * \\
\pm 0.43\end{array}$ & $\begin{array}{c}8.41 \\
\pm 0.60\end{array}$ & $\begin{array}{c}7.08 \\
\pm 0.64\end{array}$ & $\begin{array}{l}6.47 * \\
\pm 0.53\end{array}$ & $\begin{array}{c}7.99 \\
\pm 0.52\end{array}$ \\
\hline & \multicolumn{10}{|c|}{ Liver } \\
\hline $\begin{array}{c}\text { TBARs, } \\
\mu \mathrm{mol} / \mathrm{kg}\end{array}$ & $\begin{array}{l}62.53 \\
\pm 2.04\end{array}$ & $\begin{array}{l}64.11 \\
\pm 1.98\end{array}$ & $\begin{array}{l}72.06 \\
\pm 1.64\end{array}$ & $\begin{array}{l}59.32 \\
\pm 2.12\end{array}$ & $\begin{array}{l}69.33 \\
\pm 1.94\end{array}$ & $\begin{array}{l}87.54 \\
\pm 2.42\end{array}$ & $\begin{array}{l}64.02 \\
\pm 1.85\end{array}$ & $\begin{array}{l}65.84 \\
\pm 1.78\end{array}$ & $\begin{array}{l}81.23 \\
\pm 1.66\end{array}$ & $\begin{array}{l}59.83 \\
\pm 2.03\end{array}$ \\
\hline $\begin{array}{l}\text { SOD, } \\
\text { units/g }\end{array}$ & $\begin{array}{c}0.60 \\
\pm 0.02\end{array}$ & $\begin{array}{c}0.62 \\
\pm 0.03\end{array}$ & $\begin{array}{l}0,53 * \\
\pm 0.02\end{array}$ & $\begin{array}{c}0.59 \\
\pm 0.05\end{array}$ & $\begin{array}{l}0.51 * \\
\pm 0.03\end{array}$ & $\begin{array}{l}0.43^{*} \\
\pm 0.05\end{array}$ & $\begin{array}{c}0.61 \\
\pm 0.04\end{array}$ & $\begin{array}{c}0.52 \\
\pm 0.03\end{array}$ & $\begin{array}{l}0.49 * \\
\pm 0.04\end{array}$ & $\begin{array}{c}0.64 \\
\pm 0.05\end{array}$ \\
\hline
\end{tabular}

Note: * - significant differences compared to the control $(p<0.05)$.

but in 48 hours after the administration of nanoparticles were normal again.

Thus, it was proved that multi-walled functionalized $\mathrm{COOH}$ nanotubes had the most significant toxic effect.

The administration of TCM to the animals caused significant disorders of antioxidant system (Table 2). Above all, the content of TBARs in serum and liver increased significantly in all periods of the study. Significant changes of SOD activity were evidenced ( $p<0.05$ in all cases) with the maximum decrease by the $6^{\text {th }}$ hour of the experiment (in 1.7 times in serum and in 1.6 times in liver). Consecutively, CT activity and CP content, quite the opposite, were significantly increased in all periods of the study. The maximum increase of the catalase activity (in 1.9 times compare to the intact animals) was evidenced by the $6^{\text {th }}$ hour of the experiment. The concentration of another important antioxidant - GSH, under the chemical toxicant influence, decreased in 1.5, 1.7 and 1.4 times compare to the control group of animals ( $p<0.05$ in all cases). TAA decreased significantly in 1.4, 1.5 and 1.3 times in the corresponding study periods.

Table 2. The influence of tetrachloromethane on the indices of oxidative stress in blood serum and liver of rats $(M \pm m, n=8)$

\begin{tabular}{|c|c|c|c|c|}
\hline \multirow{4}{*}{ Index } & \multicolumn{4}{|c|}{ Groups of animals } \\
\hline & \multicolumn{4}{|c|}{$\mathrm{CCl}_{4}$} \\
\hline & \multirow{2}{*}{ Intact } & \multicolumn{3}{|c|}{ Time after the administration (hours) } \\
\hline & & 3 & 6 & 48 \\
\hline & \multicolumn{4}{|c|}{ Blood plasma } \\
\hline TBARs, $\mu \mathrm{mol} / \mathrm{I}$ & $7.81 \pm 0.43$ & $10.73 * \pm 0.48$ & $12.91 * \pm 0.54$ & $9.03 \pm 0.45$ \\
\hline $\mathrm{GSH}, \mathrm{mmol} / \mathrm{l}$ & $2.73 \pm 0.19$ & $1.83 * \pm 0.14$ & $1.65 * \pm 0.15$ & $1.98 * \pm 0.15$ \\
\hline $\mathrm{CT}, \mathrm{MAb} / \mathrm{I}$ & $0.67 \pm 0.04$ & $1.08 * \pm 0.06$ & $1.27 * \pm 0.07$ & $0.93 * \pm 0.03$ \\
\hline $\mathrm{CP}, \mathrm{mg} / \mathrm{l}$ & $238.4 \pm 9.20$ & $291.8 * \pm 8.47$ & $322.6 * \pm 9.02$ & $283.1 * \pm 9.11$ \\
\hline TAA, \% & $61.49 \pm 4.10$ & $44.51 * \pm 2.41$ & $41.29 * \pm 2.14$ & $47.21 * \pm 2.95$ \\
\hline \multirow[t]{2}{*}{ SOD, units/ml } & $8.33 \pm 0.54$ & $6.12 * \pm 0.38$ & $5.11 * \pm 0.42$ & $6.57 * \pm 0.39$ \\
\hline & \multicolumn{4}{|c|}{ Liver } \\
\hline TBARs, $\mu \mathrm{mol} / \mathrm{kg}$ & $62.53 \pm 2.54$ & $79.85 * \pm 3.77$ & $101.04 * \pm 3.25$ & $84.49 * \pm 2.98$ \\
\hline SOD, units/g & $0.60 \pm 0.02$ & $0.43 * \pm 0.03$ & $0.38 * \pm 0.02$ & $0.41 * \pm 0.04$ \\
\hline
\end{tabular}

Note: * - significant differences compared to the control $(p<0.05)$. 
The most significant changes in the functioning of antioxidant system were evidenced in the animals administered with total tetrahloromethane and carbon nanotubes (Table 3). In this group of animals, significant changes were evidenced in all the studied parameters compare to the intact animals in all periods of the study. It should be noted that the most of indices of the animals administered with the nanotubes+tetrachloromethane combined were significantly lower than those in the corresponding periods in the animals administered with tetrachloromethane and no nanotubes.

Table 3. The influence of combined administration of carbon nanotubes and tetrachloromethane on the indices of oxidative stress in blood serum and liver of rats $(M \pm m, n=8)$

\begin{tabular}{|c|c|c|c|c|c|c|c|c|c|c|}
\hline \multirow{3}{*}{ Index } & \multirow{3}{*}{ Intact } & \multicolumn{3}{|c|}{$\mathrm{SWNT}+\mathrm{CCl}_{4}$} & \multicolumn{3}{|c|}{$\mathrm{MWNT}+\mathrm{CCl}_{4}$} & \multicolumn{3}{|c|}{$\mathrm{MWNT}-\mathrm{COOH}+\mathrm{CCl}_{4}$} \\
\hline & & \multicolumn{9}{|c|}{ Time after the administration (hours) } \\
\hline & & 3 & 6 & 48 & 3 & 6 & 48 & 3 & 6 & 48 \\
\hline & \multicolumn{10}{|c|}{ Blood plasma } \\
\hline $\begin{array}{l}\text { TBARs, } \\
\mu \mathrm{mol} / \mathrm{I}\end{array}$ & $\begin{array}{c}7.81 \\
\pm 0.43 \\
\end{array}$ & $\begin{array}{c}10.83 * \\
\pm 0.59 \\
\end{array}$ & $\begin{array}{c}13.27 * \\
\pm 0.63\end{array}$ & $\begin{array}{l}9.92 * \\
\pm 0.57\end{array}$ & $\begin{array}{c}14.12^{* \#} \\
\pm 0.61\end{array}$ & $\begin{array}{c}16.43^{* \#} \\
\pm 0.60\end{array}$ & $\begin{array}{c}10.18 * \\
\pm 0.51\end{array}$ & $\begin{array}{c}12.53^{* \#} \\
\pm 0.57 \\
\end{array}$ & $\begin{array}{c}14.83^{* \#} \\
\pm 0.59 \\
\end{array}$ & $\begin{array}{l}9.98 * \\
\pm 0.56\end{array}$ \\
\hline $\begin{array}{l}\text { GSH, } \\
\mathrm{mmol} / \mathrm{I}\end{array}$ & $\begin{array}{c}2.73 \\
\pm 0.19 \\
\end{array}$ & $\begin{array}{l}1.68 * \\
\pm 0.10 \\
\end{array}$ & $\begin{array}{l}1.56^{*} \\
\pm 0.12 \\
\end{array}$ & $\begin{array}{l}1.92 * \\
\pm 0.14 \\
\end{array}$ & $\begin{array}{l}1.38^{* \#} \\
\pm 0.12 \\
\end{array}$ & $\begin{array}{l}1.16^{\text {*\# }} \\
\pm 0.16 \\
\end{array}$ & $\begin{array}{l}1.65 * \\
\pm 0.13 \\
\end{array}$ & $\begin{array}{l}1.44 * \\
\pm 0.10 \\
\end{array}$ & $\begin{array}{l}1.21^{\text {*\# }} \\
\pm 0.14 \\
\end{array}$ & $\begin{array}{l}1.73 * \\
\pm 0.16 \\
\end{array}$ \\
\hline $\begin{array}{l}\text { CT, } \\
M A b / I\end{array}$ & $\begin{array}{c}0.67 \\
\pm 0.04 \\
\end{array}$ & $\begin{array}{l}1.18 * \\
\pm 0.07\end{array}$ & $\begin{array}{l}1.30 * \\
\pm 0.06\end{array}$ & $\begin{array}{l}0.99 * \\
\pm 0.05\end{array}$ & $\begin{array}{l}1.33^{\text {*\# }} \\
\pm 0.06\end{array}$ & $\begin{array}{l}1.58^{\text {*\# }} \\
\pm 0.07\end{array}$ & $\begin{array}{l}1.08 * \\
\pm 0.06\end{array}$ & $\begin{array}{l}1.21 \text { * } \\
\pm 0.09\end{array}$ & $\begin{array}{l}1.51 \text { * } \\
\pm 0.08\end{array}$ & $\begin{array}{l}1.02 * \\
\pm 0.06\end{array}$ \\
\hline $\mathrm{CP}, \mathrm{mg} / \mathrm{l}$ & $\begin{array}{l}238.4 \\
\pm 9.20 \\
\end{array}$ & $\begin{array}{c}311.2^{\text {*\# }} \\
\pm 7.02\end{array}$ & $\begin{array}{c}326.9 * \\
\pm 9.61\end{array}$ & $\begin{array}{c}308.7 * \\
\pm 7.82 \\
\end{array}$ & $\begin{array}{c}321.8^{* \#} \\
\pm 8.63\end{array}$ & $\begin{array}{c}345.3^{* \#} \\
\pm 9.25\end{array}$ & $\begin{array}{c}298.1 * \\
\pm 8.08\end{array}$ & $\begin{array}{c}319.7 * \\
\pm 9.40 \\
\end{array}$ & \begin{tabular}{|c|}
$331.6 *$ \\
\pm 8.25 \\
\end{tabular} & $\begin{array}{l}289 * \\
\pm 8.22 \\
\end{array}$ \\
\hline TAA, \% & $\begin{array}{l}61.49 \\
\pm 4.10 \\
\end{array}$ & $\begin{array}{c}42.31 * \\
\pm 2.62\end{array}$ & $\begin{array}{c}37.91 * \\
\pm 3.18\end{array}$ & $\begin{array}{c}44.77^{*} \\
\pm 2.91 \\
\end{array}$ & $\begin{array}{c}38.31 * \\
\pm 2.65\end{array}$ & $\begin{array}{c}30.44^{* \#} \\
\pm 2.73\end{array}$ & $\begin{array}{c}41.63^{*} \\
\pm 2.22 \\
\end{array}$ & $\begin{array}{c}40.82^{*} \\
\pm 2.18\end{array}$ & $\begin{array}{c}34.61^{\text {*\# }} \\
\pm 2.09 \\
\end{array}$ & $\begin{array}{r}43.65 \\
\pm 3.58 \\
\end{array}$ \\
\hline $\begin{array}{l}\text { SOD, } \\
\text { units/ml }\end{array}$ & $\begin{array}{c}8.33 \\
\pm 0.54 \\
\end{array}$ & $\begin{array}{l}5.98 * \\
\pm 0.38\end{array}$ & $\begin{array}{l}5.05^{*} \\
\pm 0.32 \\
\end{array}$ & $\begin{array}{l}6.10 * \\
\pm 0.41 \\
\end{array}$ & $\begin{array}{l}5.27 * \\
\pm 0.38 \\
\end{array}$ & $\begin{array}{l}4.65 * \\
\pm 0.34 \\
\end{array}$ & $\begin{array}{l}5.49 * \\
\pm 0.39 \\
\end{array}$ & $\begin{array}{l}5.18^{*} \\
\pm 0.44\end{array}$ & $\begin{array}{l}4.82 * \\
\pm 0.39 \\
\end{array}$ & $\begin{array}{l}5.73 * \\
\pm 0.42 \\
\end{array}$ \\
\hline & \multicolumn{10}{|c|}{ liver } \\
\hline $\begin{array}{l}\text { TBARs, } \\
\mathrm{mol} / \mathrm{kg}\end{array}$ & $\begin{array}{l}62.53 \\
\pm 2.04 \\
\end{array}$ & $\begin{array}{c}87.18 * \\
\pm 2.68\end{array}$ & $\begin{array}{c}103.7 * \\
\pm 2.64\end{array}$ & $\begin{array}{l}79.5^{*} \\
\pm 2.22\end{array}$ & $\begin{array}{c}98.68^{*} \\
\pm 3.04 \\
\end{array}$ & $\begin{array}{c}118.0^{\star \#} \\
\pm 2.40\end{array}$ & $\begin{array}{c}88.66 * \\
\pm 2.13\end{array}$ & $\begin{array}{c}91.02 * \\
\pm 2.78\end{array}$ & $\begin{array}{c}106.4^{*} \\
\pm 2.51 \\
\end{array}$ & $\begin{array}{l}78.3 * \\
\pm 2.13\end{array}$ \\
\hline $\begin{array}{l}\text { SOD, } \\
\text { units/g }\end{array}$ & $\begin{array}{c}0.60 \\
\pm 0.02 \\
\end{array}$ & $\begin{array}{l}0.43 * \\
\pm 0.04 \\
\end{array}$ & $\begin{array}{l}0.34^{*} \\
\pm 0.02 \\
\end{array}$ & $\begin{array}{r}0.48 \\
\pm 0.04 \\
\end{array}$ & $\begin{array}{l}0.36 * \\
\pm 0.03 \\
\end{array}$ & $\begin{array}{l}0.28^{* \#} \\
\pm 0.02 \\
\end{array}$ & $\begin{array}{l}0.41 * \\
\pm 0.03 \\
\end{array}$ & $\begin{array}{l}0.38^{*} \\
\pm 0.03 \\
\end{array}$ & $\begin{array}{l}0.33 * \\
\pm 0.01 \\
\end{array}$ & $\begin{array}{l}0.45 * \\
\pm 0.04 \\
\end{array}$ \\
\hline
\end{tabular}

Notes: * - significant differences compared to the control $(p<0.05)$.

\# - significant differences compared to the group of animals administered with tetrachloromethane $(p<0.05)$.

\section{Discussion}

The study results brought us to the conclusion that the capability of the chemical toxicant tetrachloromethane to cause oxidative stress in serum and liver was significantly increased in case of its combined administration with carbon nanotubes. The effect of increased bioavailability of tetrachloromethane due to the capability of carbon nanotubes to absorb the toxin on its surface and to contribute to its transport to tissues and cells is the most likely explanation for the toxicity synergy of the investigated factors. According to the results of our research, as well as to the literature, nanotubes, especially MWNT, are able to induce the oxidative processes in tissues. It was established that the toxicity of nanotubes depended on their structure, size and surface area, as well as on the environment they are found in. The toxicity increased when the size of the particles decreased $[2,9]$.

\section{Conclusions}

Carbon nanotubes are able to activate the oxidative processes in the tissues of the body. The carbon nanotubes are placed in the following order by the degree of toxicity: MWNT>MWNT-COOH $>$ SWNT.

Carbon nanotubes increase the capability of the chemical toxicant tetrachloride to cause oxidative stress in liver and serum. 


\section{References}

1. Andrieyeva LI, Kozhemiakin LA, Kishkun AA. Modification of the method of lipid peroxides determination in the test using thiobarbituric acid. Laboratory Science. 1988;11:41-43.

2. Balabanov VI. Nanotechnologies. Science of the Future. Moscow: Eksmo; 2009. p. 220.

3. Kolb VG, Kamyshnikov VS. Guide to clinical chemistry. Minsk: Belarus; 1982. p. 311.

4. Koroliuk MA, Ivanova LI, Mayorova IG. Method of catalase activity determination. Laboratory Science. 1988;1:16-18.

5. Lapach SN, Chubenko AV, Babich PN. Statistical methods in biomedical research using Excel. Kyiv: Morion; 2000. p. 320.

6. Moskalenko VF, Lisovyi VM, Chekman IS, et al. Scientific fundamentals of nanomedicine, nanopharmacology and nanopharmacy. Bulletin of Science of Bogomolets National Medical University. 2009;2; 17-31.

7. Lahtin VM, Afanasiev SS, Lahtin MV, et al. Nanotechnologies and prospects for their use in medicine and biotechnology. Bulletin of RAMS. 2008;4:50-55.
8. Chevari S, Chaba I, Sekei Y. The role of superoxide dismutase in the oxidative processes of a cell and the method of its determination in biological material. Laboratory Science. 1985;11:678-681.

9. Chekman IS. Nanoparticles: properties and perspectives of usage. The Ukrainian Biochemical Journal. 2009;81(1):122-129.

10. Ellman GL. Tissue sulfhydryl groups. Archives of Biochemistry and Biophysics. 1959;82:70-77.

11. Murray AR, Kisin E, Leonard SS, et al. Oxidative stress and inflammatory response in dermal toxicity of single-walled carbon nanotubes. Toxicology. 2009 Mar 29;257(3):161-71.

12. Shvedova AA, Pietroiusti A, Fadeel B, Kagan VE. Mechanisms of carbon nanotube-induced toxicity: focus on oxidative stress. Toxicol Appl Pharmacol. 2012 Jun 1;261(2):121-33.

13. Stock J, Gutteridge JM, Sharp RJ, et al. Assay using brain homogenate for measuring the antioxidant activity of biological fluids. Clinical Science and Molecular Medicine. 1974;47:215-222.

14. Tsuda $H, X u$ J, Sakai $Y$, et al. Toxicology of engineered nanomaterials - a review of carcinogenic potential. Asian Pacific Journal of Cancer Prevention. 2009;10:975-980. 